\title{
Pain prevalence on public servants: association with sedentary behavior and physical leisure activity
}

\author{
Prevalência de dor em servidores públicos: associação com comportamento sedentário e \\ atividade física de lazer
}

José Jean de Oliveira Toscano ${ }^{1}$, Anna Cecilya Gomes Zefferino ${ }^{1}$, Jamerson Bruno Cordeiro Felix¹, Cyro Rego Cabral Júnior ${ }^{1}$, Diego Augusto Santos Silva ${ }^{2}$

DOI 10.5935/1806-0013.20160025

\section{ABSTRACT}

BACKGROUND AND OBJECTIVES: From usual actions which reflect lifestyle of those working on administrative functions, there is the sedentary behavior. This study aimed at associating prevalence of pain to sedentary behavior and physical activity level of public servants.

METHODS: Sample was made up of 156 public servants of both genders, mean age of $39.8 \pm 12.3$ years, working for a federal university of the Northeastern region of Brazil, who have answered a questionnaire with variables related to pain, sedentary behavior and practice of physical activity. For descriptive analysis data were expressed in mean, standard deviation, absolute and relative frequency. Regression analysis was used to estimate prevalence ratios and confidence interval of $95 \%$. For adjusted analysis, all variables were included in the model, considering $\mathrm{p} \leq 0.05$ significantly associated to the outcome.

RESULTS: The prevalence of sedentary behavior watching TV was $24.4 \%$ and at work it was $88.5 \%$. Approximately $65 \%$ of the sample were poorly physically active. Pain was reported by $76.3 \%$ of the sample. After adjusting for gender, age and physical activity, those spending more than two hours a day sitting watching TV and remaining sitting at work were subgroups with highest possibilities of having pain ( $\mathrm{p}<.0 .05)$.

CONCLUSION: Approximately eight out of ten employees have reported musculoskeletal pain. From investigated behaviors, it was observed that servants spending a lot of time sitting had higher probability of reporting pain.

Keywords: Adults, Employees, Musculoskeletal pain, Physical activity, Sedentary behavior.

\footnotetext{
1. Universidade Federal de Alagoas, Maceió, AL, Brasil.

2. Universidade Federal de Santa Catarina, Florianópolis, SC, Brasil.

Submitted in February 11, 2016

Accepted for publication in April 26, 2016.

Conflict of interests: none - Sponsoring sources: none.

Correspondence to:

Av. Lourival Melo Mota, s/n - Tabuleiro dos Martins

57072-900 Maceió, AL, Brasil.

E-mail: jean.toscano@hotmail.com

(C) Sociedade Brasileira para o Estudo da Dor
}

\section{RESUMO}

JUSTIFICATIVA E OBJETIVOS: Das açóes habituais que refletem o estilo de vida dos que exercem funçáo laboral administrativa, destaca-se o comportamento sedentário. O objetivo deste estudo foi associar a prevalência de dor com o comportamento sedentário e nível de atividade física de servidores públicos.

MÉTODOS: A amostra foi constituída por 156 servidores públicos, de ambos os gêneros, média de idade de 39,8 $\pm 12,3$ anos, lotados em uma universidade federal do Nordeste do Brasil, que responderam a um questionário com variáveis relativas a dor, comportamento sedentário e prática de atividade física. Para análise descritiva foram expressos valores de média, desvio padrão, frequência absoluta e relativa. Empregou-se a análise de regressão para estimativas de razôes de prevalências e intervalos de confiança de $95 \%$. Na análise ajustada, todas as variáveis foram incluídas no modelo. Considerou-se significativamente associado ao desfecho um valor de $\mathrm{p} \leq 0,05$.

RESULTADOS: A prevalência de comportamento sedentário vendo TV foi de $24,4 \%$ e no trabalho foi de $88,5 \%$. Aproximadamente $65 \%$ da amostra eram insuficientemente ativos fisicamente. A presença de dor foi reportada por $76,3 \%$ da amostra. Após ajuste pelo gênero, idade e atividade física, aqueles que passavam mais de duas horas por dia sentados à frente da TV e ficavam sentados no trabalho foram os subgrupos com maiores probabilidades de presença de dor $(\mathrm{p}<.0,05)$.

CONCLUSÁO: Aproximadamente 8 em 10 trabalhadores reportaram dor musculoesquelética. Dos comportamentos investigados foi verificado que servidores que passavam muito tempo sentados tinham maiores probabilidades de reportar dor.

Descritores: Adultos, Atividade física, Comportamento sedentário, Dor musculoesquelética, Trabalhador.

\section{INTRODUCTION}

Either chronic or acute, pain is a public health problem due to its high prevalence, high costs and negative impact on functional aspects ${ }^{1}$. Pain affects physical activities, sleep, sexual life, mood and self-esteem and leads to negative thoughts. It also changes family relationships and is among major causes of absenteeism at work ${ }^{2}$.

Workers are the most affected population by acute or chronic pain and for this reason pain-related studies should be carried out aiming at reinforcing available 
results and enhancing evidences about the relationship between factors possibly determining such outcome ${ }^{3}$. In this sense, from the set of routine actions which reflect the lifestyle of contemporary adults, especially those in administrative functions, there is the sedentary behavior, due to the high number of hours sitting to which such workers are submitted.

Decreased physical activity levels and increased time sitting have led to a complex set of relationships between daily energy expenditure and health ${ }^{4}$. Physiologic processes resulting from lack of muscle contraction may cause negative effects on major cell and molecule mechanisms, including the negative relationship of inactivity of lower limb muscles and posture maintenances.

Physical inactivity and sedentary behavior are different concepts. Individuals are physically inactive when they do not meet current physical activity recommendations ${ }^{6}$. Sedentary behavior, on the other hand, is expressed by the proportion of daily time spent in activities with intensity below 1.5 MET, especially time sitting ${ }^{7}$.

Health professionals, when identifying existing pattern in the investigated environment, may propose more effective actions for pain control.

So, the primary objective of this study was to estimate pain prevalence and to evaluate the association between this outcome with enough practice of leisure physical activity and prolonged sedentary behavior time among public servants of a city from the Northeastern of Brazil.

\section{METHODS}

This is a cross-sectional study. Target population was made up of public servants of the Universidade Federal de Alagoas - UFAL, Maceió-AL campus, Northeastern of Brazil. Studied population was made up of servants working at institution's rectory building, in a total of 310 individuals. To characterize the sample, it was determined by convenience that $50 \%$ of servants should participate in the study, being selected by simple randomized sampling. A drawing was performed in each sector considering the number of servants in that place. Each sector was previously visited to schedule time to collect relevant variables. There were seven refusals in four sectors, being replaced by servants of the same sector. At the end, participated in the study 156 servants of both genders with mean age of $39.8 \pm 12.3$ years. Outcome variable was chronic pain, being characterized as verbal report of pain for more than six months in a same site, using a dichotomous item (yes or no) ${ }^{8}$. A body map was used to locate pain, where participants were asked to indicate painful regions. Pain intensity was evaluated by means of a numeric scale graded from zero to 10 , where zero means no pain and 10 means the worst imaginable pain, being classified as follows: 1-4 (mild pain); 5-7 (moderate pain); 8-10 (severe pain) ${ }^{9,10}$.

With regard to sedentary behaviors, two indicators were used: time sitting watching TV and time sitting at work; in general these are behaviors occupying most time of people and have better measurements in terms of validity and reproducibility ${ }^{11}$. Time watching TV was dichotomized in low $(\leq 2 \mathrm{~h})$ and high $(>2 \mathrm{~h})^{2}$. At work, answers were classified in time sitting: low $(\leq 3.5 \mathrm{~h})$, moderate $(3.6$ to $5.5 \mathrm{~h})$ and high $(\geq 5.6 \mathrm{~h})^{13}$.

The leisure physical activity section of the international physical activity questionnaire (IPAQ) long form was used to identify the practice of physical activity. This component was divided into complying or not with the recommendation of 150 minutes per week of physical activity, based on IPAQ questions on hiking and practicing of moderate or intense physical activity ${ }^{14}$.

Form with relevant variables was self-applied. Data were collected by two evaluators in November and December 2014. During tool application, one evaluator would be around to solve any type of question during form filling. Participants have signed the Free and Informed Consent Term (FICT).

\section{Statistical analysis}

Data were tabulated and analyzed by the SPSS version 21 spreadsheet. Descriptive statistics with mean and standard deviation was used for age, and absolute and relative frequency was used for remaining variables. Poisson regression analysis with robust variance adjustment, raw and adjusted, was used to estimate prevalence ratios and 95\% confidence interval. In the adjusted analysis, all variables were included in the model, regardless of raw analysis $\mathrm{p}$ value. Interaction terms were verified among all predictors, however no interaction was found among variables. A value of $\mathrm{p} \leq \pm 0.05$ was considered significantly associated to the outcome.

This study was approved by UFAL Ethics Committee under registry 37817114.1.0000.5013.

\section{RESULTS}

Mean age of 156 investigated servants was $39.8 \pm 12.3$ years. Most servants were females (60.3). The prevalence of sedentary behavior watching TV was $24.4 \%(>2 \mathrm{~h} /$ day) and of sedentary behavior at work was $88.5 \%$ ( $>3,5 \mathrm{~h} /$ day). Approximately $65 \%$ of the sample were insufficiently physically active. Pain was present in $76.3 \%$ (Table 1).

Among servants reporting pain $(\mathrm{n}=119)$ (Table 2) most had excessive sedentary behavior at work and with regard to watching TV per day $(\mathrm{p}=0.038)(\mathrm{p}=0.034)$. Back pain was reported by $63.0 \%$ of those reporting pain $(\mathrm{p}=0.010)$. Raw analysis of the association between pain and independent variables has found that those spending more than two hours per day watching TV had higher probability of reporting presence of the outcome. Servants reporting sitting for more than $3.5 \mathrm{~h}$ per day at work had higher probability of reporting pain. After adjusting by gender, age and practice of physical activity, those spending more than two hours per day watching TV (PR: 1.2; CI95\%: 1.1-1.3) 
Table 1. Investigated sample characteristics

\begin{tabular}{lcc}
\hline Variables & $\mathrm{n}$ & $\%(\mathrm{Cl} 95 \%)$ \\
\hline Gender & & \\
Female & 94 & $60.3(32.2-47.7)$ \\
$\quad$ Male & 62 & $39.7(52.2-67.7)$ \\
Age (mean $\pm \mathrm{SD})$ & 156 & $39.8(12.3)$ \\
Time sitting (TV) & & \\
$\quad \leq 2 \mathrm{~h} /$ day & 118 & $75.6(68.2-81.7)$ \\
$>2 \mathrm{~h} /$ day & 38 & $24.4(18.2-31.7)$ \\
Time sitting (Work) & & \\
$\quad \leq 3.5 \mathrm{~h} /$ day & 18 & $11.5(7.3-17.6)$ \\
3.6 to 5.5h/day & 34 & $21.8(15.9-29.0)$ \\
$\geq 5.6 h /$ day & 104 & $66.7(58.8-73.6)$ \\
Physical activity & & \\
Physically active & 55 & $35.3(28.0-43.2)$ \\
Physically inactive & 101 & $64.7(56.8-71.9)$ \\
Pain & & \\
No & 37 & $23.7(17.6-31.1)$ \\
Yes & 119 & $76.3(68.8-82.3)$ \\
\hline Cl = confidence interval; SD = standard deviation. &
\end{tabular}

Table 2. Profile of people reporting pain

\begin{tabular}{|c|c|c|c|}
\hline \multirow[t]{2}{*}{ Variables } & \multicolumn{2}{|r|}{ Pain presence } & \multirow[b]{2}{*}{$p$ value } \\
\hline & $\mathrm{n}$ & \% (Cl95\%) & \\
\hline \multicolumn{4}{|l|}{ Gender } \\
\hline Female & 72 & $76.6(63.2-85.0)$ & 0.910 \\
\hline Male & 47 & $75.8(66.8-84.1)$ & \\
\hline Age $($ mean $\pm S D)$ & 119 & $40.1(12.2)$ & \\
\hline \multicolumn{4}{|l|}{ Time sitting (TV) } \\
\hline$\leq 2 \mathrm{~h} /$ day & 86 & $72.9(64.0-80.2)$ & $0.038^{*}$ \\
\hline$>2 \mathrm{~h} /$ day & 33 & 86.8 (71.1-94.6) & \\
\hline \multicolumn{4}{|l|}{ Time sitting (work) } \\
\hline$\leq 3.5 \mathrm{~h} / \mathrm{day}$ & 11 & $61.1(35.4-81.7)$ & $0.034^{*}$ \\
\hline 3.6 to $5.5 \mathrm{~h} /$ day & 31 & $91.2(74.7-97.2)$ & \\
\hline$\geq 5.6 h /$ day & 77 & $74.0(64.6-81.6)$ & \\
\hline \multicolumn{4}{|l|}{ Physical activity } \\
\hline Physically active & 41 & $74.5(61.0-84.5)$ & 0.707 \\
\hline Physically inactive & 78 & $77.2(67.8-84.4)$ & \\
\hline \multicolumn{4}{|l|}{ Back Pain } \\
\hline No & 44 & $37.0(28.6-46.1)$ & $0.010^{*}$ \\
\hline Yes & 75 & $63.0(53.8-71.3)$ & \\
\hline \multicolumn{4}{|l|}{ Pain intensity } \\
\hline Mild & 32 & $26.9(19.6-35.6)$ & 0.153 \\
\hline Moderate & 49 & $41.2(32.5-50.3)$ & \\
\hline Severe & 38 & $31.9(24.0-40.9)$ & \\
\hline
\end{tabular}

$\overline{\mathrm{Cl}}=$ confidence interval; $\mathrm{SD}=$ standard deviation; * $\mathrm{p}$-value $\leq 0.05$ (Chi-square test to compare proportions). and those remaining sitting at work $(3.6$ to $5.5 \mathrm{~h} / \mathrm{day}, \mathrm{PR}$ : 1.2; CI95\%: 1.1-1.4; $\geq 5.6 \mathrm{~h} /$ day, PR: 1.3 ; CI95\%: 1.1-1.6) were the subgroups with highest probabilities of reporting pain (Table 3).

Table 3. Poisson regression analysis with prevalence ratio estimates and $95 \%$ confidence interval of the association between pain and independent variables.

\begin{tabular}{|c|c|c|c|c|}
\hline \multirow[t]{2}{*}{ Variables } & \multicolumn{2}{|c|}{ Raw analysis } & \multicolumn{2}{|c|}{ Adjusted analysis§ } \\
\hline & PR (CI95\%) & $p$-value & PR (Cl95\%) & $p$ value \\
\hline \multicolumn{5}{|l|}{ Time sitting (TV) } \\
\hline$\leq 2 \mathrm{~h} /$ day & 1.0 & $0.039^{*}$ & 1.0 & $0.021^{*}$ \\
\hline$>2 \mathrm{~h} /$ day & $1.2(1.1-1.2)$ & & $1.2(1.1-1.3)$ & \\
\hline \multicolumn{5}{|l|}{ Time sitting (Work) } \\
\hline$\leq 3.5 \mathrm{~h} / \mathrm{day}$ & 1.0 & $0.007^{*}$ & 1.0 & $0.005^{\star}$ \\
\hline 3.6 to $5.5 \mathrm{~h} /$ day & $1.2(1.1-1.5)$ & & $1.2(1.1-1.4)$ & \\
\hline$\geq 5.6 \mathrm{~h} /$ day & $1.1(0.9-1.2)$ & & $1.3(1.1-1.6)$ & \\
\hline \multicolumn{5}{|l|}{ Physical activity } \\
\hline Physically active & 1.0 & 0.710 & 1.0 & 0.891 \\
\hline Physically inactive & $1.0(0.9-1.1)$ & & $1.1(0.9-1.2)$ & \\
\hline
\end{tabular}

\section{DISCUSSION}

Considering that one major reason for public servants medical leave, both in Brazil and in developed countries such as England and Sweden, are musculoskeletal system and connective tissue diseases ${ }^{15-17}$ It is necessary for public institutions to verify health conditions of their employees. A prevalence of $76.3 \%$ of chronic pain was found among investigated servants in this study. In a study with 505 servants of the Universidade Estadual de Londrina ${ }^{8}$, with majority also of females, an also high prevalence of $61.4 \%$ of chronic pain was found.

When identifying determining factors in a populationbased study in Brazil, the number of subjects exposed to sedentary behavior in the five investigated domains has shown that time watching TV and time sitting at work were among the three more prevalent behaviors ${ }^{18}$. Static positions maintained for long periods and frequent use of computers are factors commonly associated to muscle tension, discomfort, fatigue and musculoskeletal pain, which may evolve to decreased functional capacity and disability $^{19}$. In our study, sedentary behavior observed by means of variables watching TV and time sitting at work was significant among those reporting pain.

Overuse of chair may lead to fatigue and overload of passive joint elements, causing desensitization of tissue mechanoreceptors and consequent decrease or elimination of deep stabilizing strength, increasing the probability of musculoskeletal changes ${ }^{20}$. In a systematic review on the efficacy of ergonomic adjustments in chairs in the working place to decrease musculoskeletal symptoms, authors have con- 
cluded that amount, level and quality of evidences are just moderate and that recommendations could not be made in this sense ${ }^{21}$. It seems that sitting for long times is the major determining factor to be fought, considering that muscles helping posture maintenance suffer metabolic and neural interference when muscle contraction is decreased ${ }^{22}$.

Body region with significant prevalence of pain in the investigated population was the spine $(63 \%)$. Literature has reported that back pain is more frequent in workers spending long times in the sitting position ${ }^{23}$. Possible justification for this situation is that the sitting position may decrease joint mobility, in addition to fatiguing spinal extensor muscles, impairing spinal stability and alignment. Such biomechanical disorders are considered important etiologic factors for the development of acute and chronic back pain ${ }^{24}$. Adequate fitness levels (muscle flexibility and strength/resistance) may contribute to body posture during labor activities with energy sparing and without exceeding tolerable muscle-tissue limits, and may be a protective factor against back pain ${ }^{25}$.

With regard to pain intensity, a study with 74 patients of the Teaching Hospital, Universidade Federal do Maranhão, Brazil, has observed that most patients, especially the group of workers, have reported moderate pain (52.6\%), being that labor activity would increase pain intensity ${ }^{26}$. Among servants of our study, although a higher prevalence of moderate pain, there has been no significant difference as compared to other pain intensities. Anyway, regardless of intensity reported by employees, such pain should be prevented.

Our study has not found significant associations between leisure physical activity and pain among investigated servants. A study carried out in a university, with sample with characteristics similar to our study, has also not found association between physical activity level and presence or musculoskeletal pain ${ }^{27}$. A possible justification for this lack of association could have been the investigated physical activity domain (leisure) which may not be the most effective way to capture relationships with pain among employees spending long times sitting. This is reinforced because there are evidences that physical exercise programs in the workplace decrease the presence of musculoskeletal pain among employees ${ }^{28}$. So, if our study had investigated the domain of physical activity at work, results could have been different. Physical activity leads to muscle contraction which causes beneficial circular and metabolic adaptations of skeletal muscles and connective tissues, contributing for better static and dynamic posture, decreasing the risk of musculoskeletal and metabolic injuries and disabilities ${ }^{29-31}$. Our results confirm the literature, that is, even among people practicing moderate to intense physical activity during leisure, long time in the sitting position may promote noxious effects to health, such as the presence of pain. This suggests that such behavior, per se, is just a potential risk factor for people's health, with the need to evaluate both sedentary and physical activity behaviors ${ }^{32,33}$.

\section{CONCLUSION}

From investigated behaviors, it was observed that servants spending long times sitting (at home and at work) had higher probability of reporting pain. Strategies to decrease time sitting, both at work and at home, should be developed to try to decrease the prevalence of pain. New investigations about the causal role of sedentary behavior on health, especially musculoskeletal pain, are, then, necessary.

\section{REFERENCES}

1. Blyth F. Chronic pain--is it a public health problem? Pain. 2008;137(3):465-6

2. Salvetti MG, Pimenta CA. Validação da Chronic Pain Self-Efficacy Scale para a língua portuguesa. Rev Psiq Clín. 2005;32(4):202-10.

3. Cipriano A, Almeida DB, Vall J. Perfil do paciente com dor crônica atendido em um ambulatório de dor de uma grande cidade do sul do Brasil. Rev Dor. 2011;12(4):297-300.

4. Proper KI, Singh AS, van Mechelen M, Chinapaw MJM. Sedentary behaviors and health outcomes among adults a systematic review of prospective studies. Am J Prev Med. 2011;40(2):174-82.

5. Bey L, Akunuri N, Zhao P, Hoffman EP, Hamilton DG, Hamilton MT. Pattern of global gene expression in rat skeletal muscle during unloading and low-intensity ambulatory activity. Physiol Genomics. 2003;13(2):157-67.

6. Haskel WL, Lee IM, Pate RR, Powell KE, Blair SN, Franklin BA, et al. Physical activity and public health: updated recommendation for adults from the American College of Sports Medicine and the American Heart Association. Circulation. 2007;116:1081-93.

7. Pate RR, O'Neill JR, Lobelo F. The evolving definition of "sedentary". Exerc Sport Sci Rev. 2008;36:173-8.

8. Kreling MC, Cruz DA, Pimenta CA. Prevalência de dor crônica em adultos. Rev Bras Enferm. 2006;59(4):509-13.

9. Pimenta CA; Cruz DA; Santos JL. Instrumentos para avaliaçáo da dor: o que há de novo em nosso meio. Arq Bras Neurocir. 1998;17(1):15-24.

10. Silva JA, Ribeiro Filho NP. Avaliaçăo e mensuraçấo da dor: pesquisa, teoria e prática São Paulo: Funpec, 2006

11. Salmon J, Owen N, Crawford D, Bauman A, Sallis JF. Physical activity and sedentary behavior: a population-based study of barriers, enjoyment, and preference. Health Psychology. 2003;22(2):178-88

12. Stamatakis E, Hamer M, Dunstan DW. Screen-based entertainment time, all-cause mortality, and cardiovascular events: population-based study with ongoing mortality and hospital events follow-up. J. Am Coll Cardiol. 2011;57(3):292-9.

13. Miller R, Brown W. Steps and sitting in a working population. Int J Behav Med. 2004;11(4):219-24.

14. WHO. World Health Organization.Global recommendations on physical activity for health. Geneva: WHO; 2010.

15. Feeney A, North F, Head J, Canner R, Marmot M. Socioeconomic and sex differentials in reason for sickness absence from the Whitehaall II Study. Occup Environ Med. 1998;55(1):91-8.

16. Vingard E, Lindberg P, Josephson M, Voss M, Heijbel B, Alfredsson L, et al. Long-term sick-listing among women in the public sector and its associations with age, social situation, lifestyle, and work factors: a three-year follow-up study. Scan. J Public Health. 2005;33(5):370-5.

17. Cunha JB, Blank VL, Boing AF. Tendência temporal de afastamento do trabalho em servidores públicos (1995-2005). Rev Bras Epidemiol. 2009;12(2):226-36.

18. Mielke GI, Silva IC, Owen N, Hallal PC. Brazilian Adults' Sedentary by Life Domain population-based study. PLoS ONE. 2014;9(3):e91614.

19. Podniece Z, Taylor TN, European Agency for Safey and Health at Work. Work-related musculoskeletal disorders: prevention report. Luxembourg: Office for Official Publications of the European Communities; 2008.

20. Dankaerts W, O'Sullivan P, Burnett A, Straker L. Altered patterns of superficial trunk muscle activation during sitting in nonspecific chronic low back pain patients: importance of subclassification. Spine. 2006;31(17):2017-23

21. Niekerk S-M, Loum QA, Hiller S. The effectiveness of a chair intervention in the workplace to reduce musculoskeletal symptoms. A systematic review. BMC Musculoeskeletal Disorders. 2012;13:145.

22. Panjabi MM. A hypothesis of chronic back pain: ligament subfailure injuries lead to muscle control dysfunction. Eur Spine J. 2006;15(5):668-76.

23. Barros SS, Angelo RC, Uchôa EP. Lombalgia ocupacional e a postura sentada. Rev Dor. 2011;12(3):226-30.

24. Sacco IC, Aliberti S, Queiroz BW, Pripas D, Kieling I, Kimura AA, et al. A influência da ocupaçáo profissional na flexibilidade global e nas amplitudes angulares dos membros inferiores e da lombar. Rev Bras Cineantropom Desempenho Humano. 2009;11(1):51-8.

25. Toscano JJ, Egypto EP. A influência do sedentarismo na prevalência de lombalgia. Rev Bras Med Esporte. 2001;7(4):132-7. 
26. Garcia BT, Vieira EB, Garcia JB. Relação entre dor crônica e atividade laboral em pacientes portadores de síndromes dolorosas. Rev Dor. 2013;14(3):204-9.

27. Souza AV, Cardoso JP, Rocha SV, Amorim, CR, Carneiro, LR, Vilela AB. Nível de atividade física e lombalgia entre funcionários de uma instituição de ensino superior no nordeste do Brasil. Rev Bras Prom Saúde. 2011;24(3):199-206.

28. Lima VA, Aquilas AL, Ferreira Júnior M. Efeitos de um programa de exercícios físicos no local de trabalho sobre a percepção de dor musculoesquelética em trabalhadores de escritório. Rev Bras Med Trab. 2009;7:11-7.

29. Reis PF, Moro AR, Contijo LA. A importância da manutenção de bons níveis de flexibilidade nos trabalhadores que executam suas atividades laborais sentados. Rev Prod On
Line. 2003;3(3). Disponível em: http://producaoonline.org.br/rpo/article/view/563.

30. Souza, JB. Poderia a atividade física induzir analgesia em pacientes com dor crônica? Rev Bras Med Esporte. 2009;15(2):145-50.

31. Zderic TW, Hamilton MT. Physical inactivity amplifies the sensitivity of skeletal muscle to the lipid-induced downregulation of lipoprotein lipase activity. J Appl Physiol. 2006;100(1):249-57.

32. Castillo-Retamal M, Hinckson EA. Measuring physical activity and sedentary behavior at work: a review. Work. 2011;40(4):345-57.

33. Proper KI, Singh AS, Mechelen W, Chinapaw MJ. Sedentary behaviors and health outcomes among adults: a systematic review. Am J Prev Med. 2011;40(2):174-82. 